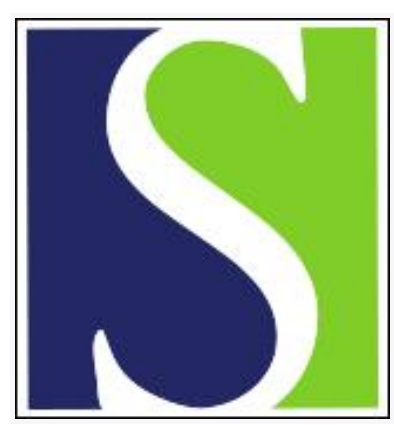

Scand J Work Environ Health 1983;9(2):103-107

https://doi.org/10.5271/sjweh.2437

Issue date: Apr 1983

Genotoxic hazards in the rubber industry.

by Sorsa M, Falck K, Maki-Paakkanen J, Vainio H

This article in PubMed: www.ncbi.nlm.nih.gov/pubmed/6648406

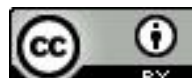

This work is licensed under a Creative Commons Attribution 4.0 International License 


\title{
Genotoxic hazards in the rubber industry
}

\author{
by Marja Sorsa, PhD, Kai Falck, PhL, Jorma Mäki-Paakkanen, BSc, \\ Harri Vainio, MD ${ }^{?}$
}

\begin{abstract}
SORSA M, FALCK K, MÄKI-PAAKKANEN J, VAINIO H. Genotoxic hazards in the rubber industry. Scand $j$ work environ health 9 (1983) 103-107. The toxicology of chemicals used in the rubber industry is poorly known. In the present investigation an attempt was made to use biological monitoring methods to identify job categories with possible exposure to potentially genotoxic chemicals. Urine samples were collected and analyzed for mutagenic activity by the bacterial fluctuation test. The highest individual mutagenic activities were detected among the workers in the weighing and mixing departments, and some high individual values were found among vulcanizers. Sister chromatid exchanges (SCE) and structural chromosome aberrations were also analyzed from samples of peripheral blood. The effect of smoking was clearly associated with significantly increased numbers of SCEs and chromosome aberrations. Among the workers in different job categories, the highest SCE frequencies were found for mixers who smoked. Also nonsmoking cleaners of the mixing department differed significantly from the nonsmoking referents in this respect. However, only the group of nonsmoking weighers showed an increase in the number of chromosome aberrations $(p<0.01)$ when compared with the referents. The results suggest the need for improved occupational hygiene in the weighing and mixing departments of rubber plants so that exposure to potentially hazardous genotoxic chemicals can be decreased.
\end{abstract}

Key terms: biological monitoring, carcinogens, chromosome aberrations, mutagens, sister chromatid exchange, urinary mutagenicity.

Several hundred chemical entities are used in the processing of rubber. The essential raw materials include various polymers, fillers, antidegradants, vulcanizing agents, accelerators, retarders, and pigments (4), and the manufacturing operations are complex. The process begins with the weighing and mixing of the raw materials, which are then masticated and milled. These procedures are followed by various extruding, calendering, and spreading operations. The product is "built" or "formed," and the rubber material is then cured or vulcanized before the final finishing of the product.

The workers involved in the manufacturing of rubber may be exposed to various noxious agents (single chemicals,

1 Department of Industrial Hygiene and Toxicology, Institute of Occupational Health, Helsinki, Finland.

Reprint requests to: Dr M Sorsa, Haartmaninkatu 1, Institute of Occupational Health, SF-00290 Helsinki 29, Finland. their reactive mixtures, or fumes released during the vulcanizing and curing processes) during the different operations. The International Agency for Research on Cancer has recently recognized the cancer risk associated with some job categories in the rubber industry (5), even though the definite causative agents have not been identified. The intention of our study was to determine whether specific biological monitoring methods can be used to pinpoint the job categories which may entail potentially harmful exposures.

\section{Subjects and methods}

The subjects of the study were 55 rubber workers employed in various job categories at two rubber plants (factories A and $B$ ) and 35 referents working mainly in office occupations either at the rubber factory or at two government institutions. Each person was interviewed as to his health status and possible confounding 
factors (recent viral infections, diagnostic radiographs, drug intake, smoking habits, and alcohol consumption). According to the obtained information, the medical records, and the recorded blood count the subjects were healthy.

The urinary mutagenicity method has been described elsewhere in detail $(1,8)$. Urine samples were obtained from 39 of the workers and 23 of the referents. The samples were taken at the end of the workday and frozen $\left(-20^{\circ} \mathrm{C}\right)$ until analyzed several months later. Our own results have indicated that such preservation has no effect on mutagenic activity. The indicator bacteria used in the fluctuation assay were Salmonella typhimurium TA98 and Escherichia coli WP2 uvrA. The final values, presented as mutagenic activity, were standardized with the concentration of creatinine in each urine sample.

The whole blood microculture method was used for the cytogenetic analyses. The culture time was $50 \mathrm{~h}$ for the chromosome aberration analysis and $68 \mathrm{~h}$ for the sister chromatid exchange (SCE) analysis. The methods have been described elsewhere in detail (6). The total material was obtained by the pooling of six separate groups of samples, cultured similarly. Every culture contained samples of both the referents and the exposed workers. The total material was analyzed on coded slides by one person, samples from factories $\mathrm{A}$ and $\mathrm{B}$ separately.

\section{Results}

\section{Urinary mutagenicity assays}

The frameshift tester strain $S$ typhimurium TA 98 is sensitive to mutagenic compounds excreted into the urine as the result of smoking. Therefore all the subjects who smoked, both the referents and the exposed workers $(N=45)$, showed significantly increased mutagenicity when compared with the nonsmokers $(\mathrm{N}=17)$, either rubber workers or referents. With this tester strain no specific variation could be seen in the mutagenic activities determined for the different job categories of nonsmokers or smokers, except between the smoking mixers of chemicals and the smoking referents (table 1).
The tester strain $E$ coli WP2 uvrA, which is sensitive to mutagens causing base pair substitutions, is an effective indicator of exposures in the rubber industry, as significantly increased urinary mutagenic activity was found among the rubber workers with this tester strain. The mean urinary mutagenic activity of the rubber workers was 1,021 (SD 624) at plant A $(N=12)$ and 492 (SD 558) at plant $B$ $(N=27)$, whereas the reference group $(\mathrm{N}=23)$ showed mutagenic activity of only 89 (SD 89). The urinary mutagenic activities determined for the different job categories at both rubber plants are presented in table 1 . The results revealed that the highest urinary mutagenic activities occurred among the workers in the weighing and mixing departments. High individual values were also found among vulcanizers.

The interindividual variation in the level of urinary mutagenic activity was high even among the subjects of the same occupational subgroup. Even a few nonsmoking referents may occasionally have a high level of urinary mutagenicity. The reason for this phenomenon is unknown.

\section{Cytogenetic assays}

The results of the analysis of the structural chromosome aberrations of the rubber workers and referents are given in table 2. No significant difference was observed in the mean frequency of the aberrations determined for the two groups. However, the nonsmoking weighers had an increased $(p<0.01)$ frequency of chromosome aberrations in their cultured blood lymphocytes in comparison to the nonsmoking referents.

A few high values were noted for the chromosome aberrations of individuals, both among the exposed workers and the referents. Most of the subjects concerned were smokers, and, as seen from the group results (table 2), the effect of smoking as an inducer of chromosome aberrations is obvious.

The SCEs were analyzed from cultures incubated with 5-bromodeoxyuridine (BrdU) and started from the same blood samples as the cultures for the chromosome analysis. The group results (mean SCE values) for the rubber workers and 
the referents, divided into smokers and nonsmokers, are given in table 3 . The effect of smoking as a potent inducer of SCEs was clearly documented in the material. The highest mean SCE frequency, differing significantly $(p<0.01)$ from that of the referents, was observed among the mixers who smoked, but also nonsmoking cleaners in the mixing department had increased SCE frequencies $(p<0.05)$ in comparison to the corresponding referents (table 3).

The highest individual SCEs were found among rubber workers who smoked, mainly workers from the mixing and weighing departments (fig 1). The 20 persons with the highest SCE frequencies included only two smokers from the reference group.

\section{Discussion}

In the rubber industry the exposure situations are enormously complex with respect to the character and number of substances handled and released in the processing of rubber. The biological monitoring of exposure is therefore an

Table 1. Urinary mutagenic activities (means and standard deviations) of the rubber workers and referents.

\begin{tabular}{|c|c|c|c|c|c|c|c|c|c|c|c|}
\hline & \multirow{2}{*}{\multicolumn{2}{|c|}{$\begin{array}{l}\text { Number of } \\
\text { subjects }\end{array}$}} & \multicolumn{9}{|c|}{ Mutagenic activity in urine } \\
\hline & & & \multirow{3}{*}{\multicolumn{2}{|c|}{$\begin{array}{c}\text { Base pair strain } \\
\text { WP2 uvrA } \\
\text { (Smokers and } \\
\text { nonsmokers) }\end{array}$}} & & \multirow{2}{*}{\multicolumn{6}{|c|}{$\begin{array}{l}\text { Frameshift strain } \\
\text { TA } 98\end{array}$}} \\
\hline & \multirow{3}{*}{$\begin{array}{l}\text { Smo- } \\
\text { kers }\end{array}$} & \multirow{3}{*}{$\begin{array}{l}\text { Non- } \\
\text { smo- } \\
\text { kers }\end{array}$} & & & & & & & & & \\
\hline & & & & & & Smok & ers & & Nonsm & kers & \\
\hline & & & Mean & SD & & Mean & SD & & Mean & $S D$ & \\
\hline $\begin{array}{l}\text { All exposed } \\
\text { workers }\end{array}$ & 30 & 9 & 655 & $622 * * *$ & & 895 & 494 & NS & 263 & 241 & NS \\
\hline $\begin{array}{l}\text { Weighers } \\
\text { Mixers } \\
\text { Calenderers } \\
\text { Vulcanizers } \\
\text { Molders } \\
\text { Cleaners }\end{array}$ & $\begin{array}{r}10 \\
9 \\
1 \\
6 \\
2 \\
2\end{array}$ & $\begin{array}{l}2 \\
3 \\
0 \\
2 \\
1 \\
1\end{array}$ & $\begin{array}{l}424 \\
750 \\
177 \\
924 \\
369 \\
926\end{array}$ & $\begin{array}{c}426 * * \\
714 * * \\
-\overline{637} * * \\
323 \\
1,011\end{array}$ & $\begin{array}{l}\text { NS } \\
\text { NS }\end{array}$ & $\begin{array}{r}769 \\
1,269 \\
670 \\
605 \\
554 \\
-\end{array}$ & $\begin{array}{l}409 \\
525^{* *} \\
-\overline{504} \\
205 \\
-\end{array}$ & $\begin{array}{l}\text { NS } \\
\text { NS }\end{array}$ & $\begin{array}{r}234 \\
437 \\
- \\
130 \\
259 \\
70\end{array}$ & $\begin{array}{r}168 \\
361 \\
- \\
91 \\
-\end{array}$ & $\begin{array}{l}\text { NS } \\
\text { NS } \\
\text { NS } \\
\text { NS } \\
\text { NS }\end{array}$ \\
\hline Referents & 15 & 8 & 89 & 89 & & 671 & 424 & & 297 & 207 & \\
\hline
\end{tabular}

** $p<0.01, * * * p<0.001, N S=$ not significant (difference from the reference group, one-tailed t-test).

Table 2. Chromosome aberrations, including gaps, among the smoking and nonsmoking rubber workers and referents. (100 cells analyzed per individual)

\begin{tabular}{|c|c|c|c|c|c|c|}
\hline & \multicolumn{3}{|c|}{ Smokers } & \multicolumn{3}{|c|}{ Nonsmokers } \\
\hline & \multirow{2}{*}{$N$} & \multicolumn{2}{|c|}{$\begin{array}{l}\text { Chromosome } \\
\text { aberrations }\end{array}$} & \multirow{2}{*}{$N$} & \multicolumn{2}{|c|}{$\begin{array}{l}\text { Chromosome } \\
\text { aberrations }\end{array}$} \\
\hline & & Mean & $\mathrm{SD}$ & & Mean & $\mathrm{SD}$ \\
\hline All exposed workers & 31 & 6.0 & 3.2 & 24 & 4.8 & 2.8 \\
\hline $\begin{array}{l}\text { Weighers } \\
\text { Mixers } \\
\text { Tire builders } \\
\text { Vulcanizers } \\
\text { Cleaners } \\
\text { Molders }\end{array}$ & $\begin{array}{r}8 \\
10 \\
4 \\
6 \\
1 \\
2\end{array}$ & $\begin{array}{l}6.0 \\
6.8 \\
3.3 \\
6.0 \\
9.0 \\
5.5\end{array}$ & $\begin{array}{l}2.1 \\
2.2 \\
3.3 \\
5.4 \\
0.7\end{array}$ & $\begin{array}{l}4 \\
4 \\
4 \\
8 \\
3 \\
1\end{array}$ & $\begin{array}{l}7.5 \\
5.3 \\
2.5 \\
4.6 \\
3.0 \\
9.0\end{array}$ & $\begin{array}{l}3.7^{a} \\
3.3 \\
1.0 \\
1.8 \\
1.0 \\
-\end{array}$ \\
\hline Referents & 14 & 6.6 & $2.8 \mathrm{a}$ & 21 & 4.2 & 1.8 \\
\hline
\end{tabular}

a $p<0.01$ (compared with nonsmokers in the reference group, chi-square test). 
Table 3. Sister chromatid exchanges (SCEs) among the rubber workers and referents.

\begin{tabular}{|c|c|c|c|c|c|c|}
\hline & \multicolumn{3}{|c|}{ Smokers } & \multicolumn{3}{|c|}{ Nonsmokers } \\
\hline & \multirow{2}{*}{$\mathrm{N}$} & \multicolumn{2}{|c|}{ SCEs } & \multirow{2}{*}{$\mathbf{N}$} & \multicolumn{2}{|c|}{ SCEs } \\
\hline & & Mean & $\mathrm{SD}$ & & Mean & SD \\
\hline All exposed workers & 31 & 13.0 & $1.9 \mathrm{a}$ & 24 & 11.6 & $1.4 \mathrm{~b}$ \\
\hline $\begin{array}{l}\text { Weighers } \\
\text { Mixers } \\
\text { Tire builders } \\
\text { Vulcanizers } \\
\text { Cleaners } \\
\text { Molders }\end{array}$ & $\begin{array}{r}8 \\
10 \\
4 \\
6 \\
1 \\
2\end{array}$ & $\begin{array}{l}12.6 \\
13.7 \\
13.1 \\
12.4 \\
16.4 \\
12.0\end{array}$ & $\begin{array}{l}2.1 \\
1.3 \mathrm{c}, \mathrm{d} \\
3.1 \\
1.6 \\
1.2\end{array}$ & $\begin{array}{l}4 \\
4 \\
4 \\
8 \\
3 \\
1\end{array}$ & $\begin{array}{l}11.6 \\
11.2 \\
11.3 \\
11.7 \\
12.2 \\
12.5\end{array}$ & $\begin{array}{l}1.2 \\
1.1 \\
1.3 \\
1.9 \\
1.0 \mathrm{e}\end{array}$ \\
\hline Referents & 14 & 12.2 & $1.3^{t}$ & 21 & 10.5 & 1.0 \\
\hline $\begin{array}{ll}\text { a } & p<0.01 \text { (all expos } \\
\text { b } & p<0.01 \text { (all expos } \\
\text { c } & p<0.01 \text { (smoking } \\
\text { d } & p<0.05 \text { (smoking } \\
\text { e } & p<0.05 \text { (nonsmoki } \\
\text { f } & p<0.001 \text { (smoking }\end{array}$ & $\begin{array}{l}\text { vs al } \\
\text { kers v } \\
\text { moking } \\
\text { nonsn } \\
\text { vs ne } \\
\text { s nons }\end{array}$ & $\begin{array}{l}\text { exposed } \\
\text { nonsmoki } \\
\text { referents, } \\
\text { king mixe } \\
\text { smoking r } \\
\text { loking ref }\end{array}$ & $\begin{array}{l}\text { okers, } \\
\text { erents, } \\
\text { iled S } \\
\text { e-taile } \\
\text { ts, one } \\
\text { one-t }\end{array}$ & $\begin{array}{l}\text { Stud } \\
\text { d Stu } \\
\text {-test). } \\
\text { 's t-te } \\
\text { udent } \\
\text { dent's }\end{array}$ & $\begin{array}{l}\text { s t-test } \\
\text { t's t-tes } \\
\text { test). } \\
\text { est). }\end{array}$ & \\
\hline
\end{tabular}

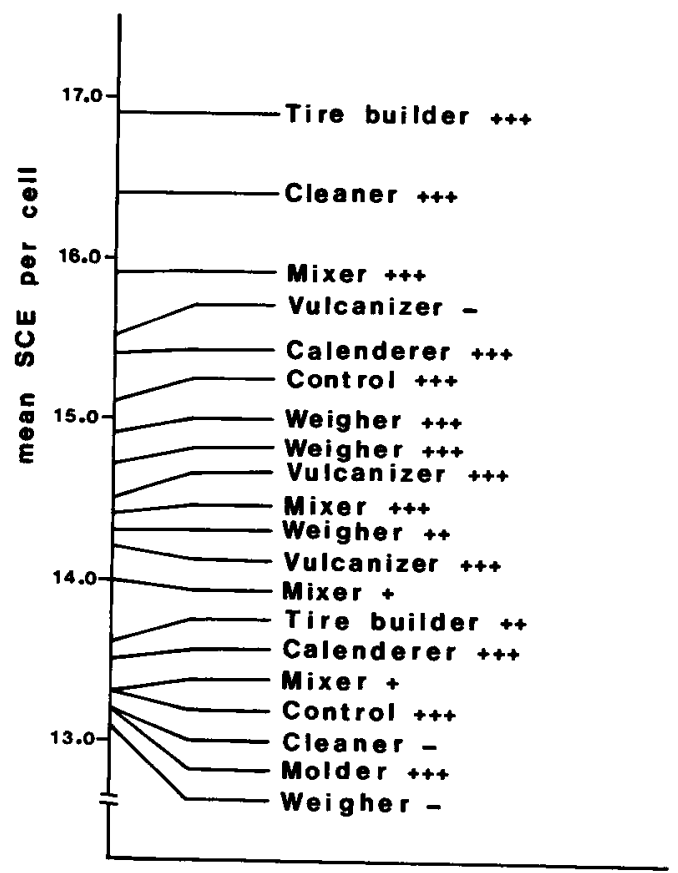

Fig 1. The highest individual sister chromatid exchange values per cell among the rubber workers $(N=55)$ and the referents $(N=35)$. (Smoking habits: $t=1-10,++=11-19$ and $++=\geq 20$ cigarettes a day, $-=$ nonsmoker)

important method for the identification of potential genotoxic risks. The correlation of the results from the biological samples with experimental findings about the mutagenicity and carcinogenicity of single rubber chemicals and curing emissions is necessary for the identification of specific risk factors. Many rubber chemicals and vulcanizing fumes have been shown to be mutagenic in bacteria $(2,3)$.

Earlier results on the applicability of the urinary mutagenicity assay for monitoring exposure in the rubber industry have shown the advantage of using two bacterial strains, both $S$ typhimurium TA98 and $E$ coli WP2 uvrA, in distinguishing the occupational exposures from the effect of smoking (1). The significant differences in the exposures which occur in various jobs have also been discussed previously $(7,8,10)$. Our results, supplemented by the material obtained from factory $B$, where technical rubber products are manufactured, confirmed the earlier findings from plant $\mathrm{A}$ by pointing to the genotoxic exposures occurring especially in the mixing, weighing, and vulcanizing operations.

The results of the SCE analyses have been discussed in an earlier publication (9). When they were compared with data on structural chromosome aberrations, the concordance of the two parameters, both of which reveal damage of deoxyribonucleic acid in the blood lymphocytes, was not very good. The sensitivity of the 
analysis of structural chromosome aberrations is questionable, especially when the tedious work effort needed to accomplish the analyses is considered. Furthermore, the confounding effect of smoking, which was found not only for SCEs but also for chromosome aberrations, complicate the inferences drawn from the results.

However, the results of the SCE and the chromosome aberration analyses suggest that chromosome damage may be induced in persons working in the chemical mixing and weighing operations of rubber factories. The elimination of such exposures before they manifest themselves as health effects is a matter of great concern.

\section{Acknowledgments}

We wish to express our sincere thanks to Ms H Järventaus and Ms V Kytöniemi for their excellent technical assistance in the laboratory. Thanks are also due to the health care personnel of Nokia Oy for their help in obtaining the samples and to Ms S Hinkkanen for the linguistic revision of the text.

The study was economically supported by the Swedish Work Environment Fund (79: 188-2).

\section{References}

1. Falck K, Sorsa M, Vainio H, Kilpikari I. Mutagenicity in urine of workers in rubber industry. Mutat res 79 (1980) 45-52.

2. Hedenstedt A, Ramel C, Wachtmeister CA. Mutagenicity of rubber vulcanization gases in Salmonella typhimurium. $J$ toxicol environ health 8 (1981) 805-814.

3. Hedenstedt A, Rannug U, Ramel C, Wachtmeister CA. Mutagenicity and metabolism studies on 12 thiuram and dithiocarbamate compounds used as accelerators in the Swedish rubber industry. Mutat Res 68 (1979) $313-325$.

4. Holmberg B, Sjöström B, Olsson S. A toxicological survey of chemicals used in the Swedish rubber industry and proposals for the elimination of chemical hazards in the rubber industry. National Board of Occupational Safety and Health, Stockholm 1977. (Investigation report 19).

5. International Agency for Research on Cancer. Monographs on the evaluation of the carcinogenic risk of chemicals to humans: The rubber industry. Lyon 1982. (Volume 28).

6. Mäki-Paakkanen J, Husgafvel-Pursiainen K, Kalliomäki P-L, Tuominen J, Sorsa M. Toluene-exposed workers and chromosome aberrations. $\mathrm{J}$ toxicol environ health 6 (1980) $775-781$.

7. Sorsa $M$, Falck $K$, Norppa $H$, Vainio $H$. Monitoring genotoxicity in the occupational environment. Scand $j$ work environ health 7 (1981): suppl 4, 61-65.

8. Sorsa M, Falck $\mathrm{K}$, Vainio $H$. Detection of worker exposure to mutagens in the rubber industry by the use of the urinary mutagenicity assay. In: Sugimura T, Kondo S, Takebe H, ed. Environmental mutagens and carcinogens. University of Tokyo Press, Tokyo 1982, pp 323-329.

9. Sorsa M, Mäki-Paakkanen J, Vainio $H$. Identification of mutagen exposures in the rubber industry by the sister chromatid exchange method. Cytog cell genet (in press).

10. Vainio H, Falck $\mathrm{K}$, Mäki-Paakkanen J, Sorsa M. Possibilities for identifying genotoxic risks in the rubber industry: Use of the urinary mutagenicity assay and sister chromatid exchange. In: Armstrong B, Bartsch H, ed. Environmental host factors in carcinogenesis. International Agency for Research on Cancer, Lyon (in press). 